\title{
ANALISIS PENYELESAIAN TUGAS PROBABILITAS SISWA SD DITINJAU DARI PERBEDAAN KEMAMPUAN MATEMATIKA DAN GENDER
}

\author{
Dwi Ivayana Sari ${ }^{1}$, I Ketut Budayasa ${ }^{2}$, Dwi Juniati ${ }^{3}$ \\ ${ }^{1}$ STKIP PGRI Bangkalan, ${ }^{2,3}$ Universitas Negeri Surabaya \\ E-mail: dwiivayanasari@yahoo.com ${ }^{1)}$,ketutbudayasa@yahoo.com ${ }^{2)}$, \\ dwi_juniati@yahoo.com ${ }^{3)}$
}

\begin{abstract}
This study is aimed to analyze probabilistic thinking of elementary school students based on math ability and gender differences. Descriptive explorative approach was used to describe in depth probabilistic thinking of boys with high, middle, low math ability and girls with high, middle, low math ability. The result showed that probabilistic thinking of boy with high math ability indicated multistructural because his thinking quantitative and proportional. While probabilistic thinking of boys with middle, low math ability and girls with high, middle, low math ability indicated unistructural because their thinking quantitative and non proportional. Beside that, boys' thinking in solving probability tasks was more analytical and flexible than girls' thinking. So, students with math ability difference, gave difference response in solving probability tasks. This result found new strategy in solving probability comparison task. This result could contribute to curriculum developer to introduce probability in elementary school level and teachers could use discussion method in teaching probability material.
\end{abstract}

Keywords: Probabilistic Thinking, Elementary School Students, Math Ability, Gender

\section{PENDAHULUAN}

Matematika merupakan bidang studi yang dikenalkan kepada siswa sejak dia duduk di bangku Sekolah Dasar (SD). Kurikulum matematika SD/MI yang dikembangkan oleh tim pengembang kurikulum bertujuan agar pembelajaran matematika mengenalkan siswa tentang konsep, kemampuan dan strategi berpikir terkait kehidupan sehari-hari.

Ada 3 materi pokok matematika yang termuat dalam kurikulum matematika SD di Indonesia, yaitu: (1) bilangan, (2) geometri dan pengukuran, dan (3) pengolahan data. Pada materi pengolahan data, salah satu kompetensi dasar yang harus dikuasai oleh siswa berdasarkan kurikulum KBK dan KTSP adalah menaksir hasil pengolahan data. Sedangkan berdasarkan kurikulum 2013 adalah menyatakan kesimpulan berdasarkan data. Menaksir dan menyatakan kesimpulan berarti siswa diminta untuk memprediksi dan selanjutnya menarik suatu kesimpulan berdasarkan informasi data yang sudah diolah. Untuk mencapai kompetensi ini, maka siswa SD tidak hanya mampu berpikir deterministik saja, namun siswa SD harus mampu berpikir probabilistik. Hal ini sesuai dengan pendapat Lamprianou \& Lamprianou (2002) bahwa berpikir probabilistik adalah salah satu penalaran yang mencoba untuk mengukur ketidakpastian, dan sebagai alat untuk pengambilan kesimpulan.

Di samping itu, manusia tidak hanya dihadapkan pada masalah yang sudah terjadi dan sedang terjadi. Namun, manusia juga dihadapkan pada masalah yang akan terjadi. Masalah yang akan terjadi erat kaitannya dengan situasi yang tidak pasti. Sehingga manusia tidak cukup mampu berpikir deterministik saja dalam menghadapinya, namun manusia harus mampu berpikir probabilistik dalam menghadapinya. Hal ini dikarenakan menurut pendapat Jones, Langrall, Thornton, \& Mogill (1999), Lamprianou \& Lamprianou (2002) dan Savard (2014) bahwa berpikir 
probabilistik sebagai berpikir seseorang dalam menanggapi situasi yang melibatkan ketidakpastian. Lebih lanjut, Falk dan Konold (Pfannkuch \& Brown, 1996) menjelaskan bahwa berpikir probabilistik adalah suatu cara baru memproses informasi ketika pandangan dunia berubah dari pandangan deterministik mengenai realita. Jadi, berpikir probabilistik berbeda dengan berpikir deterministik, lebih lanjut Savard (2014) menjelaskan bahwa berpikir probabilistik merupakan berpikir dibawah ketidakpastian, artinya hasil dipilih secara acak, sehingga tidak ada korelasi antara hasil dengan apa yang terjadi sebelumnya. Namun, berpikir deterministik merupakan sebuah pencarian korelasi, menggunakan informasi saat ini dan masa lalu untuk menjelaskan suatu fenomena.

Berdasarkan pentingnya berpikir probabilistik di atas, maka pembelajaran matematika di jenjang SD seharusnya mengembangkan berpikir probabilitik siswa. Salah satu konsep dalam matematika yang dapat mengembangkan berpikir probabilistik adalah probabilitas. Hal ini karena probabilitas adalah cara untuk menggambarkan kejadian yang tidak dapat dijelaskan melalui pengertian sebab akibat atau deterministik (Langrall \& Mooney, 2005). Menurut Halpern (Hirsch \& O’Donnell, 2001) probabilitas adalah ilmu tentang kemungkinan dan ketidakpastian. Lebih lanjut, Nikiforidou (2010) dan Way (2008) probabilitas didefinisikan sebagai kuantifikasi percobaan dan komponennya adalah keacakan dan penerapan pemikiran proporsional.

Di Indonesia, probabilitas belum dikenalkan di jenjang SD. Padahal probabilitas sangat penting bagi statistika yaitu terutama dalam menaksir serta mengambil kesimpulan.
Seharusnya probabilitas dikenalkan pertama kali bersamaan dengan statistika. Hal ini dapat membantu siswa untuk mengembangkan pola berpikir probabilistik sejak dini, yaitu sejak siswa duduk di bangku SD, sehingga memiliki pondasi yang lebih kuat untuk belajar lebih lanjut mengenai statistika dan probabilitas di tingkat yang lebih tinggi. Disamping itu, ada beberapa hasil penelitian yang menunjukkan keberhasilan siswa kelas rendah (TK dan SD) dalam menyelesaikan tugas probabilitas (Way, 2003; Kafoussi, 2004; Mousoulide, 2009; HodnikCadez, 2011)

Berpikir probabilistik siswa dalam menyelesaikan tugas probabilitas dapat dilihat dari beberapa aspek, diantaranya adalah respon (Sharma, 2012), strategi (Acredolo, O'Conor, Banks \& Horobin, 1989; English, 1991; Falk \&Wilkening, 1998; Jones et. al, 1999, Langrall \& Mooney, 2005) dan representasi (Jones et. al, 1999; Drier, 2000; Kvatinsky, 2002). Sharma (2012) mengembangkan empat kategori respon yang terdiri dari non respon, respon non statistik, respon statistik partial dan respon statistik. Deskripsi non respon adalah siswa tidak dapat menjelaskan pemikirannya dan sering menebak jawaban, sebagai contoh, saya tidak tahu, saya lupa aturannya, saya hanya menebak. Deskripsi respon non statistik adalah siswa menghubungkan dengan pengalamannya sehari-hari, keyakinan, keberuntungan, takhayul atau agama. Deskripsi respon statistik partial adalah siswa mengadaptasi aturan dan menggunakannya dengan tidak tepat, biasanya menghubungkan dengan keterwakilan, kesalapahaman proporsional, dan bias equiprobability. Deskripsi respon statistik adalah siswa menjelaskan pemikirannya dengan menggunakan interpretasi klasik atau 
frekuentis, menggunakan probabilitas numerik serta mendaftar ruang sampel.

Acredolo, dkk (1989) menemukan 3 strategi yang digunakan siswa SD dalam menyelesaikan tugas probabilitas yaitu numerator, denumerator dan interaksi keduanya (gabungan). Lebih lanjut, Langrall \& Mooney (2005) menjelaskan deskripsi ketiga strategi tersebut. Deskripsi numerator adalah siswa memeriksa bagian dari himpunan yang sesuai dengan kejadian target. Deskripsi denumerator adalah siswa memeriksa bagian yang sesuai dengan komplemen kejadian. Deskripsi gabungan adalah siswa menghubungkan banyaknya elemen target dengan total banyaknya elemen dalam himpunan itu. Berkaitan dengan strategi, Falk \& Wilkening (1998) menemukan 4 strategi yang digunakan siswa SD dalam menyelesaikan tugas probabilitas yaitu strategi proporsional (PRO), strategi selisih (DIF) dan strategi satu dimensi (OD). Strategi satu dimensi dibagi menjadi 2 yaitu memeriksa banyaknya elemen menang (W) dan memeriksa banyaknya elemen kalah (L). Lebih lanjut, Langrall \& Mooney (2005) memberikan nama lain yaitu strategi satu dimensi menang (ODW) disebut more of the target event, strategi satu dimensi kalah (ODL) disebut less of the non target event( $s)$. Strategi selisih (DIF) disebut a greater difference in favor of the target event. Selain itu, Jones et. al (1997) dan Polaki (2002) juga mengembangkan kerangka untuk mendeskripsikan berpikir siswa SD pada tugas probabilitas yang difokuskan pada strategi yang digunakan oleh siswa SD. Kerangka tersebut terdiri dari subjective, transitional, informal quantitative dan numerical.

Money (2014) mengidentifikasi kerangka berpikir yang menonjol dengan menggunakan taksonomi SOLO sebagai dasar untuk menggolongkan perkembangan berpikir siswa, yang terdiri dari (1) Prestructural probabilistic thinking menunjukkan bahwa pemikiran siswa tidak relevan, tidak matematis, atau pribadi, (2) unistructural probabilistic thinking menunjukkan bahwa pemikiran siswa adalah kuantitatif dan non-proporsional, (3) multistructural probabilistic thinking menunjukkan bahwa pemikiran siswa adalah kuantitatif dan proporsional, dan (4) relational probabilistic thinking menunjukkan bahwa pemikiran siswa adalah interkoneksi ide-ide probabilistik.

Berpikir probabilistik setiap individu dalam menyelesaikan tugas probabilitas adalah berbeda dan tergantung kepada sejauh mana ia mampu memahami tugas probabilitas yang dihadapi, sejauh mana ia merespon dan menggunakan strategi. Respon dan strategi yang digunakan seseorang berbeda-beda tergantung dari kemampuan matematika masingmasing. Selain itu, perbedaan proses berpikir probabilistik juga dipengaruhi oleh aspek hubungan sosial dan budaya. Gender merupakan salah satu yang membedakan laki-laki dan perempuan dari aspek hubungan sosial dan budaya. Menurut Santrock (2003) gender merujuk pada konsep laki-laki atau perempuan berdasarkan dimensi sosial budaya dan psikologi. Adapun hasil penelitian Yenilmez et. al (2005) yang menunjukkan bahwa anak laki-laki memiliki nilai lebih tinggi dibandingkan anak perempuan pada penalaran probabilistik. Hal ini sesuai dengan penelitian Paul (2014) yang menyatakan bahwa ada perbedaan yang signifikan dalam tingkat kognitif probabilitas siswa berdasarkan gender, laki-laki memiliki lebih sedikit miskonsepsi dibandingkan dengan perempuan. Namun, Mari (2012) dalam penelitiannya menyatakan bahwa tidak 
ada perbedaan signifikan antara subjek laki-laki dan perempuan pada penalaran penalaran probabilistik. Hal ini sesuai dengan hasil penelitian Lamprianou \& Lamprianou (2003) yang menyatakan bahwa gender tidak terlihat memiliki efek yang banyak pada respon siswa.

Berdasarkan beberapa hasil penelitian yang telah dipaparkan menunjukkan bahwa perlu adanya penyelidikan untuk mengungkap kemungkinan alasan di balik hasil-hasil penelitian di atas melalui penggunaan metode penelitian kualitatif. Artinya bahwa perlu untuk menganalisis penyelesaian tugas probabilitas siswa SD berdasarkan taxonomy berpikir probabilistik ditinjau dari kemampuan matematika dan perbedaan gender.

\section{METODE PENELITIAN}

Jenis penelitian ini adalah penelitian deskriptif eksploratif yang bertujuan untuk mendeskripsikan secara mendalam tentang berpikir probabilistik siswa SD. Peneliti merupakan instrumen utama dalam penelitian ini (Moleong, 2009; Creswell, 2013). Subjek dalam penelitian ini adalah siswa kelas 5 di suatu sekolah dasar di Bangkalan Madura. Pemilihan subjek penelitian melalui pemberian tes kemampuan matematika. Setelah diperoleh skor kemampuan matematika setiap siswa, maka peneliti memilih subjek yang terdiri dari siswa laki-laki berkemampuan matematika tinggi, sedang dan rendah serta siswa perempuan berkemampuan matematika tinggi, sedang dan rendah.

Setelah diperoleh 6 subjek, setiap subjek diberi tugas. Setelah selesai mengerjakan, setiap subjek diwawancarai untuk menggali lebih mendalam bagaimana subjek berpikir dan memperoleh informasi baru yang mungkin tidak dapat diperoleh dari tugas yang dikerjakan subjek. Data jawaban tertulis dan hasil wawancara dianalisis, dikategorisasi, direduksi dan diinterpretasikan untuk membuat kesimpulan. Kredibilitas data menggunakan triangulasi waktu.

Instrumen tugas probabilitas dalam penelitian ini terdiri dari probabilitas suatu kejadian dan perbandingan probabilitas. Berikut ini soal tugas probabilitas yang diberikan kepada subjek penelitian.

1. Probabilitas suatu kejadian. Disediakan sebuah kotak berisi bola dengan jenis dan ukuran yang sama. Bola tersebut adalah 4 bola merah, 3 bola biru dan 2 bola hijau. Jika kamu diminta untuk mengambil satu bola dari dalam kotak dengan mata tertutup, maka bola warna apa yang paling mungkin terambil? Berikan alasanmu!

2. Perbandingan probabiltias. Disediakan 2 kotak berisi spidol dengan jenis dan ukuran yang sama. Kotak I berisi 2 spidol hitam dan 6 spidol merah. Kotak II berisi 4 spidol hitam dan 8 spidol merah. Kamu diminta mengambil satu spidol dari dalam kotak dengan menutup mata. Jika kamu ingin mendapatkan spidol berwarna merah, maka sebaiknya kamu mengambil spidol dari kotak mana? Berikan alasanmu!

\section{HASIL PENELITIAN DAN PEMBAHASAN}

Berdasarkan hasil tes kemampuan matematika, maka diperoleh 6 siswa untuk diwawancarai berbasis tugas.

Jawaban tertulis dan cuplikan hasil wawancara dan hasil analisis dari keenam subjek dijelaskan berikut ini.

\section{Berpikir Probabilistik Siswa Laki- Laki Berkemampuan Matematika Tinggi}

Jawaban tertulis siswa laki-laki berkemampuan matematika tinggi (LT) 
ISSN 2089-8703 (Print) Vol. 7, No. 1 (2018)

ISSN 2442-5419 (Online)

dalam menyelesaikan tugas probabilitas

Gambar 1.

suatu kejadian dapat dilihat pada

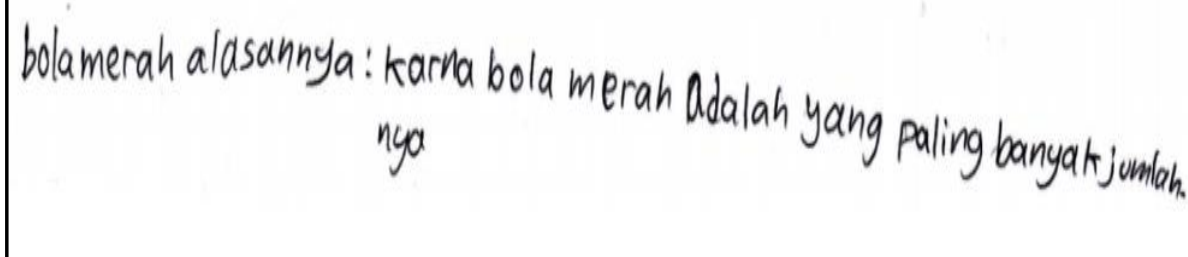

Gambar 1. Jawaban tertulis LT pada tugas probabilitas suatu kejadian

Adapun cuplikan wawancara LT

dalam memprediksi probabilitas/

peluang suatu kejadian pada tugas

probablitas suatu kejadian sebagai berikut.

$\mathrm{P}_{1}$ Berapa besar kemungkinan terambilnya bola merah?

$\mathrm{LT}_{1} \quad$ Emmm,, 4/9. Kalau pake pecahan $4 / 9$.
$\mathrm{P}_{2} \quad$ Kenapa kok 4/9?

$\mathrm{LT}_{2} \quad$ Karena kalau dalam pecahan jumlah bola merah per,,, jumlah bola merah per jumlah semua bola.

Jawaban tertulis siswa laki-laki berkemampuan matematika tinggi (LT) dalam menyelesaikan tugas perbandingan probabilitas dapat dilihat pada Gambar 2.

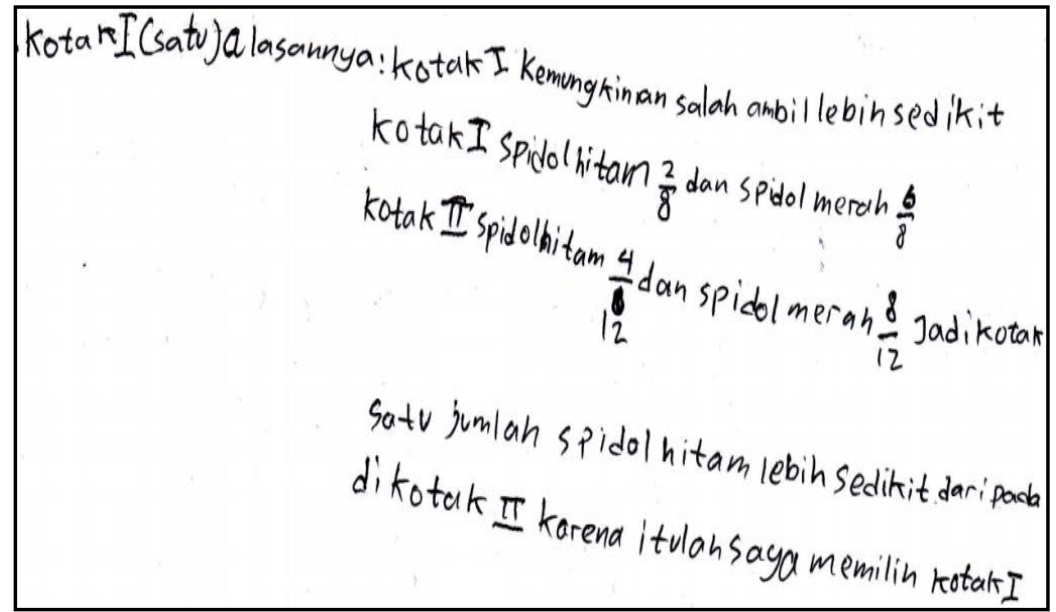

Gambar 2. Jawaban tertulis LT pada tugas perbandingan probabilitas

Adapun cuplikan wawancara LT

dalam memprediksi probabilitas/ peluang suatu kejadian pada tugas perbandingan probabilitas sebagai berikut.

$\mathrm{P}_{1} \quad$ Berapa peluang mendapatkan spidol berwarna merah di kotak I?

$\mathrm{LT}_{1} \quad$ Di kotak I, 2/8, eh,, yang merah 6/8

$\mathrm{P}_{2} \quad$ Kemudian spidol merah di kotak II?

$\mathrm{LT}_{2} \quad$ Eee,,, spidol merah di kotak II 8/12.

$\mathrm{P}_{3} \quad$ Coba jelaskan 6/8 itu kenapa di kotak I?

$\mathrm{LT}_{3} \quad 6 / 8$ itu jumlah spidol merah per spidol hitam dan spidol merah di kotak I. Kalau dikecilkan jadi 3/4. Jadi, di kotak II 2/3.

Berdasarkan paparan jawaban tertulis dan hasil wawancara, siswa lakilaki berkemampuan matematika tinggi memberikan respon statistik karena dia menggunakan interpretasi klasik dan probabilitas numerik dalam memprediksi kemungkinan terjadinya suatu kejadian. Dia menggunakan strategi numerator dalam menyelesaikan tugas probabilitas suatu kejadian dan menggunakan strategi less of the target 
event(s) dalam menyelesaikan tugas terkait perbandingan probabilitas. Ini menunjukkan bahwa dia menggunakan ratio dan perhitungan dalam menduga situasi probabilitas, sehingga dapat disimpulkan bahwa pemikiran siswa laki-laki berkemampuan matematika tinggi termasuk berpikir probabilistik multistruktural karena pemikirannya kuantitatif dan proporsional.

\section{Berpikir Probabilistik Siswa Laki- Laki Berkemampuan Matematika Sedang}

Jawaban tertulis siswa laki-laki berkemampuan matematika sedang (LS) dalam menyelesaikan tugas probabilitas suatu kejadian dapat dilihat pada Gambar 3.

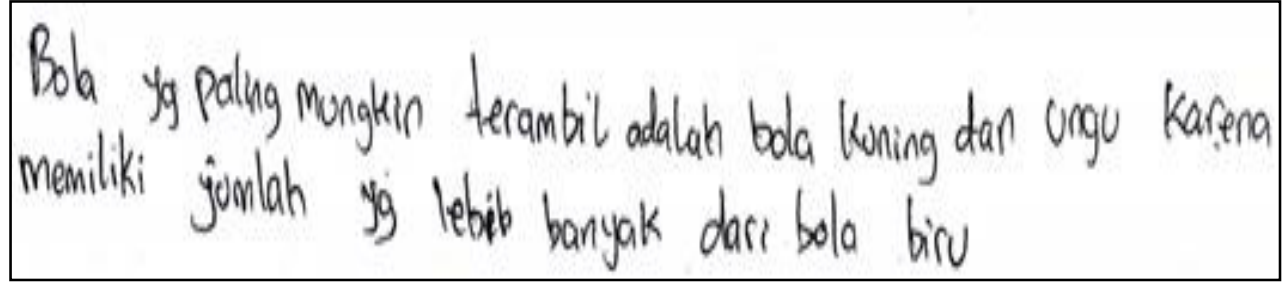

Gambar 3. Jawaban tertulis LS pada tugas probabilitas suatu kejadian

Adapun cuplikan wawancara LS dalam memprediksi probabilitas/ peluang suatu kejadian pada tugas probablitas suatu kejadian sebagai berikut.

$\mathrm{P}_{1} \quad$ Berapa kemungkinan terambilnya bola warna kuning?

$\mathrm{LS}_{1} \quad$ Bola merah kira-kira $80 \%$,

$\mathrm{P}_{2} \quad$ Kalau bola ungu dan biru?

$\mathrm{LS}_{2} \quad$ Bola ungu kira-kira $15 \%$ dan bola biru $5 \%$.

$\mathrm{P}_{3} \quad$ Kenapa bola merah kemungkinannya kuning $80 \%$, bola ungu $15 \%$ dan bola biru $5 \%$ ?

$\mathrm{LS}_{3} \quad$ Karena bola kuning paling banyak jadi kemungkinannya menurut saya kirakira $80 \%$, kemudian terbanyak kedua bola ungu kira-kira $15 \%$ dan bola biru kemungkinanya $5 \%$.

Jawaban tertulis siswa laki-laki berkemampuan matematika sedang (LS) dalam menyelesaikan tugas perbandingan probabilitas dapat dilihat pada Gambar 4.

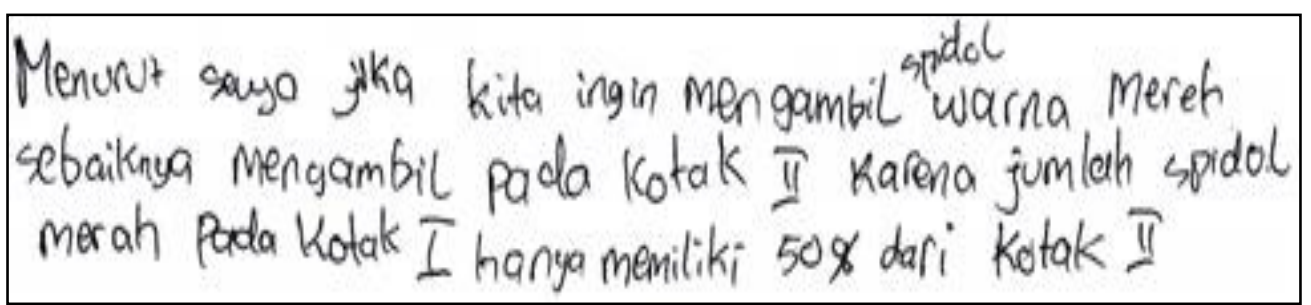

Gambar 4. Jawaban tertulis LS pada tugas perbandingan probabilitas

Adapun cuplikan wawancara LR dalam memprediksi probabilitas/ peluang suatu kejadian pada tugas perbandingan probabilitas sebagai berikut.

$P_{1} \quad$ Berapa kesempatan terambilnya spidol merah di kotak II?

$\mathrm{LS}_{1} \quad$ Kira-kira $80 \%$ karena 20\%nya kesempatan terambilnya spidol hitam.
Berdasarkan paparan jawaban tertulis dan hasil wawancara, siswa lakilaki berkemampuan matematika sedang memberikan respon statistik parsial karena responnya mengacu pada kesalahpahaman proporsional dalam memprediksi kemungkinan terjadinya suatu kejadian. Dia menggunakan strategi numerator dalam menyelesaikan 
tugas probabilitas suatu kejadian dan menggunakan strategi more of the target event dalam menyelesaikan tugas terkait perbandingan probabilitas. Ini menunjukkan bahwa dia membuat prediksi dengan menggunakan kuantitas, sehingga dapat disimpulkan bahwa pemikiran siswa laki-laki berkemampuan matematika sedang termasuk berpikir probabilistik unistruktural karena pemikirannya kuantitatif dan non proporsional.

Berpikir Probabilistik Siswa LakiLaki Berkemampuan Matematika Rendah

Jawaban tertulis siswa laki-laki berkemampuan matematika rendah (LR) dalam menyelesaikan tugas probabilitas suatu kejadian dapat dilihat pada Gambar 5.

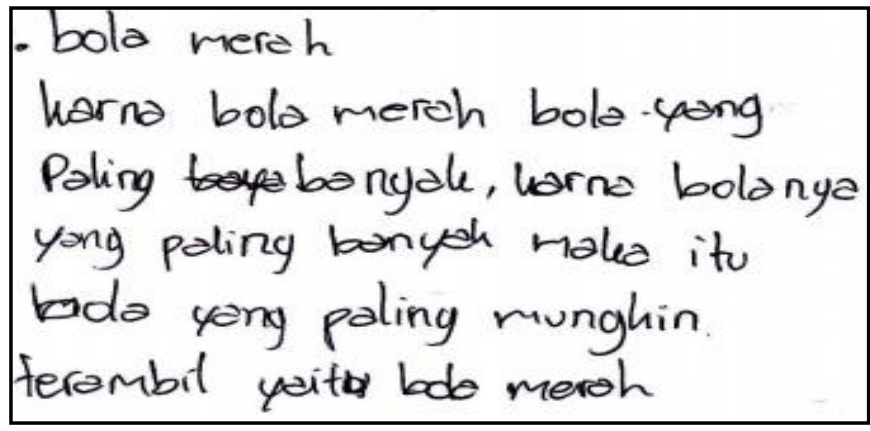

Gambar 5. Jawaban tertulis LR pada tugas probabilitas suatu kejadian

Adapun cuplikan wawancara LR dalam memprediksi probabilitas/ peluang suatu kejadian pada tugas probablitas suatu kejadian sebagai berikut.

$\mathrm{P}_{1} \quad$ Berapa keterjaminan terambilnya bola warna merah?

$\mathrm{LR}_{1}$ Emmm,, tergantung jumlahnya.. Emmm,,, (melihat soal) 4 bola merah, 3 bola biru, 2 bola hijau. Selisih satu sih sama bola biru. Bola hijau gak begitu soalnya jumlahnya 2 . Kalau andaikan misalnya bola merah itu ada
98, kalau misalnya bola hijaunya ada 2. Kan sulit diambil bola hijau, paling sering kena merah gitu. Ini kace' satu sama bola biru, selisih satu. Kalau biru dengan hijau selisih satu. Kalau bola merah dengan hijau selisih dua. Kalau ditanya berapanya,, berapa ya,, (sambil berpikir) emmm,, gak tahu

Jawaban tertulis siswa laki-laki berkemampuan matematika rendah (LR) dalam menyelesaikan tugas perbandingan probabilitas dapat dilihat pada Gambar 6.

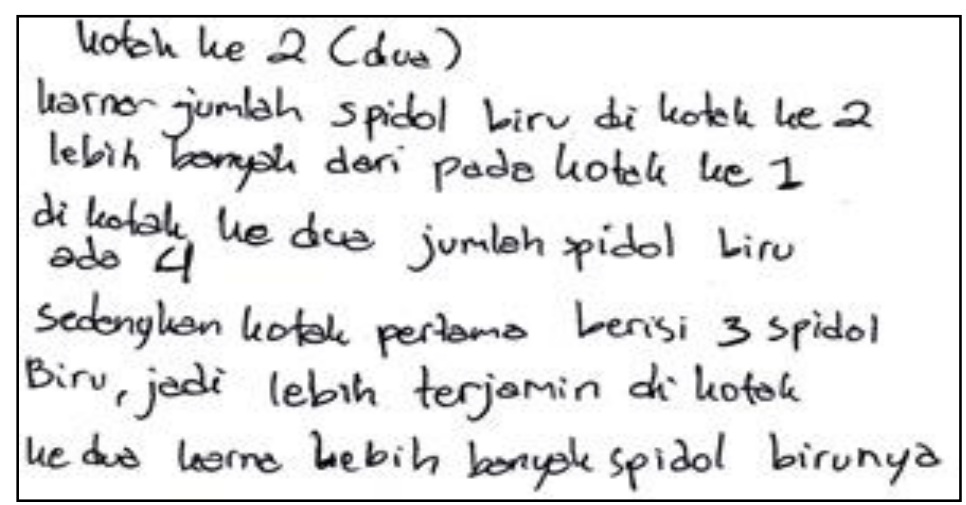

Gambar 6. Jawaban tertulis LR pada tugas perbandingan probabilitas 
Adapun cuplikan wawancara LR dalam memprediksi probabilitas/ peluang suatu kejadian pada tugas perbandingan probabilitas sebagai berikut.

$\mathrm{P}_{1} \quad$ Seberapa besar kemudahan untuk mendapatkan spidol merah di kotak II?

$\mathrm{LR}_{1} \quad$ (Berpikir selama 16 detik) sekitar 60\% bu menurut saya bu.

$\mathrm{P}_{2} \quad$ Kenapa kok 60\%?

$\mathrm{LR}_{2}$ Iya,,, karena di sini saya anggap spidol hitam itu 40\%, tetapi di sini bukan 6 . Biar jadi $100 \%$ ya, sekitar 60 lah, iya,,, sekitar situ. Gak anu saya bu kalau matematika gak tahu (sambil tersenyum).

Berdasarkan paparan jawaban tertulis dan hasil wawancara, siswa lakilaki berkemampuan matematika rendah memberikan respon statistik parsial karena responnya mengacu pada kesalahpahaman proporsional dalam memprediksi kemungkinan terjadinya suatu kejadian. Dia menggunakan strategi numerator dalam menyelesaikan tugas probabilitas suatu kejadian dan menggunakan strategi more of the target event dalam menyelesaikan tugas terkait perbandingan probabilitas. Ini menunjukkan bahwa dia membuat prediksi dengan menggunakan kuantitas, sehingga dapat disimpulkan bahwa pemikiran siswa laki-laki berkemampuan matematika rendah termasuk berpikir probabilistik unistruktural karena pemikirannya kuantitatif dan non proporsional.

\section{Berpikir Probabilistik Siswa Perempuan Berkemampuan Matematika Tinggi}

Jawaban tertulis siswa perempuan berkemampuan matematika tinggi (PT) dalam menyelesaikan tugas probabilitas suatu kejadian dapat dilihat pada Gambar 7.

\section{merah, karena jumlahnya paling banyak}

Gambar 7. Jawaban tertulis PT pada tugas probabilitas suatu kejadian

Adapun cuplikan wawancara PT
dalam memprediksi
probabilitas/peluang suatu kejadian
pada tugas probablitas suatu kejadian
sebagai berikut.
$\mathrm{P}_{1}$ Seberapa besar kemudahan untuk
mendapatkan bola merah?
$\mathrm{PT}_{1}$ 70\%.
$\mathrm{P}_{2}$ Kenapa kamu menyatakan

kemudahannya itu 70\%?

$\mathrm{PT}_{2} \quad$ Karena kan kalau $100 \%$ pasti dapetnya warna merah, karena masih ada warna yang lain, warna biru sama hijau. Jadi, $70 \%$.

Jawaban tertulis siswa perempuan berkemampuan matematika tinggi (PT) dalam menyelesaikan tugas perbandingan probabilitas dapat dilihat pada Gambar 8 .

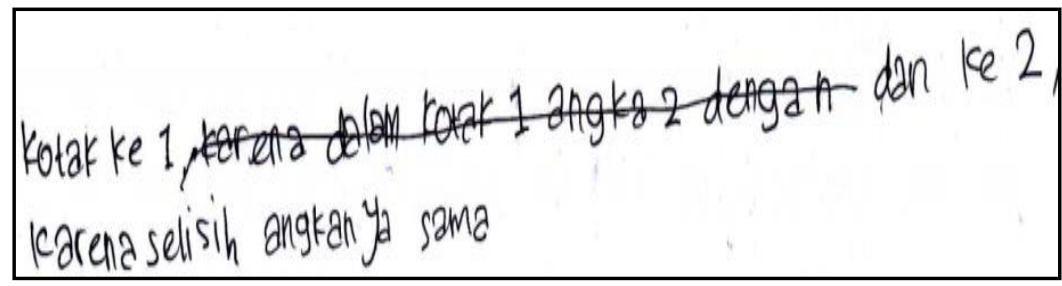

Gambar 8. Jawaban tertulis PT pada tugas perbandingan probabilitas 
Adapun cuplikan wawancara PT dalam memprediksi probabilitas/ peluang suatu kejadian pada tugas perbandingan probabilitas sebagai berikut.

$\mathrm{P}_{1} \quad$ Coba kamu sebutkan seberapa besar kemudahan untuk mendapatkan spidol merah di kotak I, kemudian nanti sebutkan di kotak II?

$\mathrm{PT}_{1} \quad$ Yang kotak I dulu ya bu,,, yang dapat spidol merah $80 \%$, yang di kotak II $80 \%$, oh,,, ndak bu, spidol merah di kotak I $80 \%$ dan di kotak II $60 \%$.

$\mathrm{P}_{2} \quad$ Kenapa kalau di kotak I untuk mendapatkan spidol merahnya itu $80 \%$ ?

$\mathrm{PT}_{2}$ Karena jumlah spidol hitam lebih sedikit daripada kotak II.

Berdasarkan paparan jawaban tertulis dan hasil wawancara, siswa perempuan berkemampuan matematika tinggi memberikan respon statistik parsial karena responnya mengacu pada kesalahpahaman proporsional dalam memprediksi kemungkinan terjadinya suatu kejadian. Dia menggunakan strategi numerator dalam menyelesaikan tugas probabilitas suatu kejadian dan menggunakan strategi a greater difference in favor of the target event dalam menyelesaikan tugas terkait perbandingan probabilitas. Ini menunjukkan bahwa dia membuat prediksi dengan menggunakan kuantitas, sehingga dapat disimpulkan bahwa pemikiran siswa perempuan berkemampuan matematika tinggi termasuk berpikir probabilistik unistruktural karena pemikirannya kuantitatif dan non proporsional.

\section{Berpikir Probabilistik Siswa Perempuan Berkemampuan Matematika Sedang} Jawaban tertulis siswa perempuan berkemampuan matematika sedang (PS) dalam menyelesaikan tugas probabilitas suatu kejadian dapat dilihat pada Gambar 9.

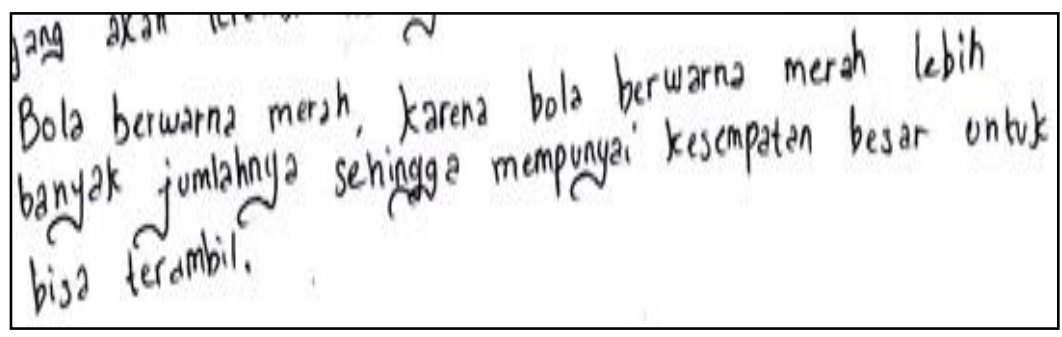

Gambar 9. Jawaban tertulis PS pada tugas probabilitas suatu kejadian

Adapun cuplikan wawancara PS dalam memprediksi probabilitas/ peluang suatu kejadian pada tugas probablitas suatu kejadian sebagai berikut.

$\mathrm{P}_{1} \quad$ Berapa kemungkinan terambilnya bola merah?

$\mathrm{PS}_{1} \quad$ Ehm,,, menurut saya $80 \%$ karena jumlahnya paling banyak.

$\mathrm{P}_{2} \quad$ Boal biru dan hijau?

$\mathrm{PS}_{2} \quad$ Sama-sama $10 \%$ sehingga jadi $100 \%$. Jawaban tertulis siswa perempuan berkemampuan matematika sedang (PS) dalam menyelesaikan tugas perbandingan probabilitas dapat dilihat pada Gambar 10. 


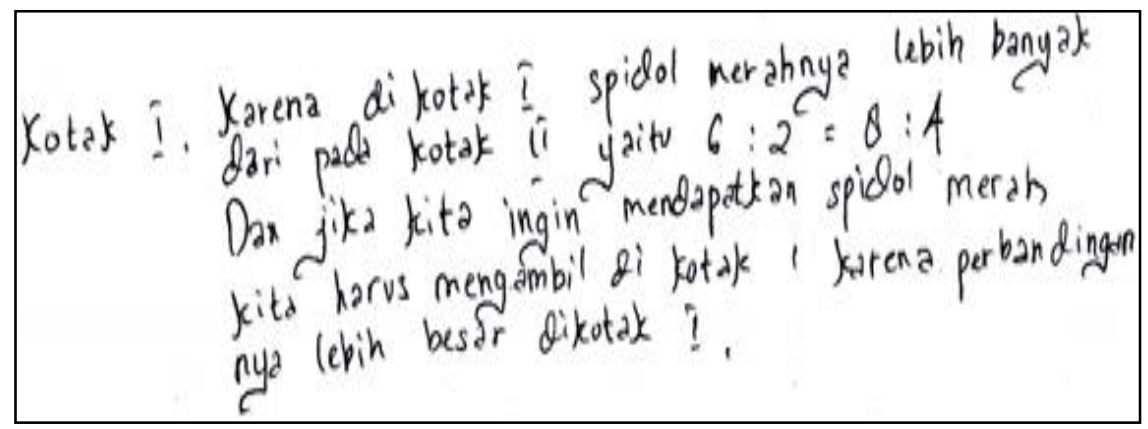

Gambar 10. Jawaban tertulis PS pada tugas perbandingan probabilitas

\section{Adapun cuplikan wawancara PS dalam memprediksi probabilitas/peluang suatu kejadian pada tugas perbandingan probabilitas sebagai berikut. \\ . $\mathrm{P}_{1}$ Berapa besar kemungkinan terambilnya spidol merah di kotak I? \\ $\mathrm{PS}_{1} \quad$ Menurut saya 70\% karena 30nya mungkin terambil spidol hitam.}

Berdasarkan paparan jawaban tertulis dan hasil wawancara, siswa perempuan berkemampuan matematika sedang memberikan respon statistik parsial karena responnya mengacu pada kesalahpahaman proporsional dalam memprediksi kemungkinan terjadinya suatu kejadian. Dia menggunakan strategi numerator dalam menyelesaikan tugas probabilitas suatu kejadian dan menggunakan strategi baru yang disebut dengan a greater quotient in favor of the target event dalam menyelesaikan tugas terkait perbandingan probabilitas, karena dia memeriksa himpunan dengan hasil bagi yang lebih besar dalam mendukung target kejadian. Ini menunjukkan bahwa dia membuat prediksi dengan menggunakan kuantitas, sehingga dapat disimpulkan bahwa pemikiran siswa perempuan berkemampuan matematika sedang termasuk berpikir probabilistik unistruktural karena pemikirannya kuantitatif dan non proporsional.

\section{Berpikir Probabilistik Siswa Perempuan Berkemampuan Matematika Rendah}

Jawaban tertulis siswa perempuan berkemampuan matematika rendah (PR) dalam menyelesaikan tugas probabilitas suatu kejadian dapat dilihat pada Gambar 11.

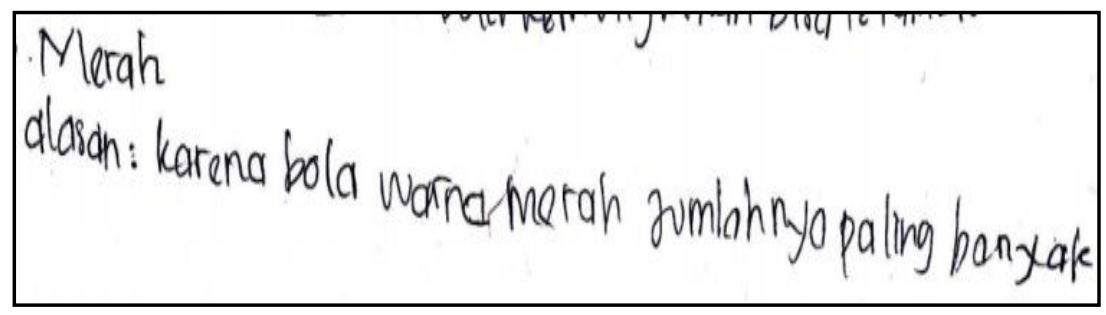

Gambar 11. Jawaban tertulis PR pada tugas probabilitas suatu kejadian

Adapun cuplikan wawancara PR dalam memprediksi probabilitas/ peluang suatu kejadian pada tugas probablitas suatu kejadian sebagai berikut.

$\mathrm{P}_{1}$ Berapa besar kemungkinan terambilnya bola merah?
$\mathrm{PR}_{1} \quad$ Emmm,,, 50\%.

$\mathrm{P}_{2}$ Coba jelaskan kenapa kemungkinan terambilnya bola merah $50 \%$ ?

$\mathrm{PR}_{1}$ Karena $50 \%$ nya lagi bola lain dapat terambil.

Jawaban tertulis siswa perempuan berkemampuan matematika rendah (PR) 
dalam menyelesaikan tugas pada Gambar 12. perbandingan probabilitas dapat dilihat

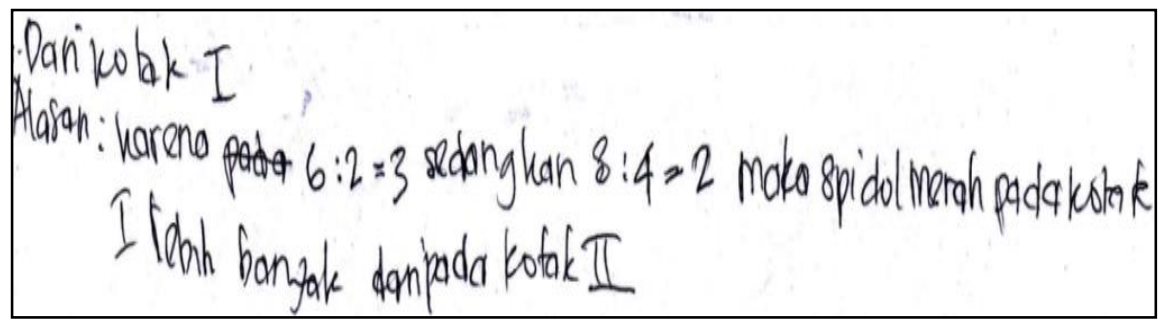

Gambar 12. Jawaban tertulis PR pada tugas perbandingan probabilitas

Adapun cuplikan wawancara PR dalam memprediksi probabilitas/ peluang suatu kejadian pada tugas perbandingan probabilitas sebagai berikut.

$\mathrm{P}_{1} \quad \mathrm{Nah}$, sekarang berapa besar kemungkinan mendapatkan spidol merah di kotak I?

$\mathrm{PR}_{1} \quad$ Emmm,, $60 \%$.

$\mathrm{P}_{2} \quad$ Kenapa kok 60\% coba jelaskan?

$\mathrm{PR}_{2}$ Karena 40\%nya spidol merah dapat terambil dari kotak II.

$\mathrm{P}_{3} \quad$ Kenapa $60 \%$ spidol merah terambil di kotak I dan $40 \%$ spidol merah terambil di kotak II?

$\mathrm{PR}_{3} \quad$ Karena kemungkinan dapat terambil di kotak I, spidol merah di kotak I lebih besar.

Berdasarkan paparan jawaban tertulis dan hasil wawancara, siswa perempuan berkemampuan matematika rendah memberikan respon statistik parsial karena responnya mengacu pada kesalahpahaman proporsional dalam memprediksi kemungkinan terjadinya suatu kejadian. Dia menggunakan strategi numerator dalam menyelesaikan tugas probabilitas suatu kejadian dan menggunakan strategi baru yang disebut dengan a greater quotient in favor of the target event dalam menyelesaikan tugas terkait perbandingan probabilitas, karena dia memeriksa himpunan dengan hasil bagi yang lebih besar dalam mendukung target kejadian. Ini menunjukkan bahwa dia membuat prediksi dengan menggunakan kuantitas, sehingga dapat disimpulkan bahwa pemikiran siswa perempuan berkemampuan matematika rendah termasuk berpikir probabilistik unistruktural karena pemikirannya kuantitatif dan non proporsional.

Hasil analisis data penelitian di atas menunjukkan bahwa pemikiran siswa laki-laki berkemampuan matematika tinggi termasuk berpikir probabilistik multistruktural karena pemikirannya kuantitatif dan proporsional. Sedangkan pemikiran siswa laki-laki berkemampuan matematika sedang dan rendah, serta siswa perempuan berkemampuan matematika tinggi, sedang dan rendah termasuk berpikir probabilistik unistruktural karena pemikirannya kuantitatif dan non proporsional.

Berdasarkan hasil analisis setiap tugas yang diberikan, menunjukkan bahwa pemikiran siswa laki-laki dalam menyelesaikan tugas probabiltias lebih analitis dan fleksibel daripada siswa perempuan. Hal ini sesuai dengan pendapat Dagun (1992) yang menyatakan bahwa cara berpikir lakilaki dan perempuan berbeda, yakni lakilaki lebih analitis dan fleksibel dibandingkan perempuan. Begitu juga menurut pendapat Jensen (2011) yang menyatakan bahwa pria umumnya berkinerja melebihi wanita dalam penalaran matematika. Hasil penelitian ini juga sejalan dengan hasil penelitian Yenilmez dkk (2005) yang menghasilkan bahwa anak laki-laki 
memiliki nilai lebih tinggi dibandingkan anak perempuan pada penalaran proporsional dan penalaran probabilistik. Hasil ini juga sejalan dengan hasil penelitian Sari, dkk (2017b) yang menunjukkan bahwa level berpikir probabilistik siswa laki-laki lebih tinggi daripada siswa perempuan. Hasil penelitian inipun juga sejalan dengan hasil penelitian Paul (2014) yang menyatakan bahwa laki-laki memiliki lebih sedikit miskonsepsi dibandingkan dengan perempuan.

Selain itu, hasil penelitian ini menunjukkan bahwa siswa yang memiliki kemampuan matematika berbeda, juga memberikan respon yang berbeda pula dalam menyelesaikan tugas probabilitas. Hasil penelitian ini sesuai dengan hasil penelitian Jones (1999), Polaki (2002a) dan Sari, dkk (2017a) yang menyatakan bahwa tingkat kemampuan matematika yang berbeda, maka berbeda pula dalam hal berpikir probabilistik. Berkaitan dengan kemampuan matematika dan gender, hasil penelitian ini sejalan dengan Sari (2015b) bahwa siswa laki-laki berkemampuan matematika tinggi dapat mendaftar anggota himpunan semua hasil yang mungkin untuk ruang sampel dua dimensi berbentuk soal cerita bahkan dia menggunakan strategi odometer, sedangkan hasil penelitian Sari (2015c) menunjukkan bahwa siswa perempuan berkemampuan memberikan respon non-statistik dalam menyelesaikan ruang sampel dua dimensi berbentuk soal cerita karena responnya mengau pada pengalamannya sehari-hari.

Hasil penelitian ini juga menemukan satu strategi baru yang digunakan oleh siswa SD dalam menyelesaikan tugas probabilitas yaitu a greater quotient in favor of the target event karena siswa memeriksa himpunan dengan hasil bagi yang lebih besar dalam mendukung target kejadian. Sehingga hasil penelitian ini melengkapi hasil penelitian Langrall \& Mooney (2005).

Hasil penelitian ini mengungkapkan bahwa siswa SD mampu merespon serta menggunakan suatu strategi dalam menyelesaikan setiap tugas probabilitas yang diberikan baik probabilitas suatu kejadian maupun perbandingan probabilitas. Hasil penelitian ini sesuai dengan hasil penelitian Sari (2015a) yang menghasilkan bahwa siswa menggunakan strategi odometer dalam menyelesaikan tugas ruang sampel dan menggunakan representasi berupa daftar. Selain itu, siswa menggunakan strategi numerator dalam menyelesaikan tugas probabilitas suatu kejadian dan menggunakan representasi berupa model luas serta siswa menggunakan strategi perbedaan yang lebih besar dalam mendukung target dalam menyelesaikan tugas perbandingan probabilitas dan menggunakan representasi berupa proporsional suatu bilangan. Berdasarkan kemampuan siswa SD dalam menggunakan strategi serta representasi dalam menyelesaikan masalah yang memuat unsur ketidakpastian ini, maka hasil penelitian ini memberikan implikasi terhadap perkembangan kurikulum matematika SD. Artinya pengembang kurikulum matematika SD dapat memasukkan materi probabilitas sebagai bagian dari materi pengolahan data. Hal ini dikarenakan statistika dan probabilitas sama-sama berhubungan dengan kejadian dari suatu percobaan atau eksperimen. Jika statistika merupakan ilmu yang mempelajari tentang cara mengumpulkan data, menyajikan data, menganalisis data dan menaksir serta mengambil kesimpulan berdasarkan data yang telah diperoleh dari suatu percobaan, maka probabilitas 
merupakan ilmu yang mempelajari tentang menaksir suatu hasil yang mungkin terjadi dari suatu percobaan. Sehingga probabilitas ini erat kaitannya dengan pengambilan kesimpulan dari statistika berdasarkan data yang diperoleh, dengan cara memprediksi (menaksir) berdasarkan informasi data yang diberikan. Selain itu, materi probabilitas dapat mengembangkan berpikir probabilistik siswa SD sejak dini. Sehingga siswa memiliki fondasi yang kuat untuk mengembangkan berpikir probabilistik dan mempelajari materi probabilitas di tingkat selanjutnya.

Selain itu, hasil penelitian ini dapat dijadikan masukan bagi guru SD untuk mengajarkan materi probabilitas dengan menggunakan metode pembelajaran dan media pembelajaran yang tepat. Metode pembelajaran yang dapat digunakan adalah metode diskusi dengan membentuk kelompok diskusi yang heterogen dalam hal kemampuan matematika dan gender. Hal ini dikarenakan berdasarkan hasil penelitian, terdapat perbedaan pemikiran probabilistik antara siswa laki-laki dan perempuan, begitu pula kemampuan matematika yang berbeda, maka berbeda pula dalam merespon tugas probabilitas. Sehingga melalui metode diskusi, setiap anggota dalam kelompok dapat saling berdiskusi dan berinteraksi dalam menyelesaikan tugas berkaitan dengan probabilitas. Media pembelajaran yang dapat digunakan dapat berupa media spinner. Hal ini sesuai dengan hasil penelitian Sari, dkk (2018) yang menyatakan bahwa bentuk spinner seperti lingkaran, sehingga dapat mengembangkan strategi numerik sederhana ke dalam penalaran proporsional dalam menanggapi tugas probabilitas.

\section{KESIMPULAN DAN SARAN}

Siswa laki-laki berkemampuan matematika tinggi termasuk berpikir probabilistik multistruktural karena pemikirannya kuantitatif dan proporsional. Sedangkan pemikiran siswa laki-laki berkemampuan matematika sedang dan rendah, serta siswa perempuan berkemampuan matematika tinggi, sedang dan rendah termasuk berpikir probabilistik unistruktural karena pemikirannya kuantitatif dan non proporsional. Selain itu, disimpulkan bahwa pemikiran siswa laki-laki dalam menyelesaikan tugas probabiltias lebih analitis dan fleksibel daripada siswa perempuan. Kemudian siswa yang memiliki kemampuan matematika berbeda, juga memberikan respon yang berbeda pulan dalam menyelesaikan tugas probabilitas. Hasil penelitian ini juga menghasilkan strategi baru dalam menyelesaikan tugas terkait perbandingan probabilitas yaitu $a$ greater quotient in favor of the target event. Hasil ini dapat dijadikan masukan bagi pengembang kurikulum SD untuk memasukkan materi probabilitas guna mengembangkan berpikir probabilistik siswa sejak siswa duduk di bangku SD. Dengan demikian, siswa SD sejak dini sudah mampu berpikir probabilistik dan dapat dikembangkan di jenjang selanjutnya. Hal ini dikarenakan berpikir probabilistik sangat penting bagi kehidupan manusia dalam menghadapi situasi yang memuat unsur ketidakpastian. Selain itu, metode diskusi dapat digunakan oleh guru dalam mengenalkan materi probabilitas kepada siswa SD.

\section{DAFTAR PUSTAKA}

Acredolo, C., O'Conor, J., Banks, L., \& Horobin, K. 1989. Children's Ability to Make Probability Estimates: Skills Revealed through Application of 
Anderson's Functional Measurement Methodology. Child Development. Vol. 60, No. 4, Hal 933-945.

Creswell, J. W. 2013. Research design pendekatan kualitatif, kuantitatif, dan mixed. Yogyakarta: Pustaka Pelajar.

Dagun, S. M. 1992. Maskulin dan femin im: Perbedaan pria dan wanita dalam fisiologi. Jakarta: Rineka Cipta.

Drier, H. S. 2000. Children's Probabilistic Reasoning with a Computer Microworld. Doctoral dissertation: The College of William and Mary.

English, L. D. 1991. Young Children's Combinatoric Strategies. Educational Studies in Mathematics. Vol. 22, No. 5, Hal 451-474.

Falk, R., \& Wilkening, F. 1998. Children's Construction of Fair Chances: Adjusting Probabilities. Developmental psychology. Vol. 34, No. 6, Hal. 1340-1357.

Hirsch, L. S., \& O’Donnell, A. M. 2001. Representativeness in Statistical Reasoning: Identifying and Assessing misconceptions. Journal of Statistics Education. Vol. 9, No. 2, Hal 61-82.

HodnikČadež, T., \& Škrbec, M. 2011. Understanding the Concepts in Probability of Pre-school and Early School Children. Eurasia Journal of Mathematics, Science \& Technology Education. Vol. 7, No. 4, Hal 263-279.

Jensen, E. 2011. Pembelajaran Berbasis-Otak Paradigma Pengajaran Baru Edisi Kedua. Jakarta: PT Indeks.

Jones, G. A., Langrall, C. W., Thornton, C. A., \& Mogill, A. T. 1997. A framework for assessing and nurturing young children's thinking in probability. Educational studies in Mathematics. Vol. 32, No. 2, Hal 101-125.

Jones, G. A., Langrall, C. W., Thornton, C. A., \& Mogill, A. T. 1999. Students' probabilistic thinking in instruction. Journal for Research in Mathematics Education, Hal 487519.

Kafoussi, S. 2004. Can kindergarten children be successfully involved in probabilistic tasks. Statistics Education Research Journal. Vol. 3, No. 1, Hal. 29-39.

Kvatinsky, T., \& Even, R. 2002. Framework for teacher knowledge and understanding about probability. In Proceedings of the Sixth International Conference on Teaching Statistics (CD). Cape Town, South Africa: International Statistical Institute.

Lamprianou, I., \& Afantiti Lamprianou, T. 2002. The nature of pupils' probabilistic thinking in primary schools in Cyprus. In PME Conference. Vol. 3, Hal 3-273.

Lamprianou, I., \& Lamprianou, T. A. 2003. The Probabilistic Thinking of Primary School Pupils in Cyprus: The Case of Tree Diagrams. International Group for the Psychology of Mathematics Education. Vol. 3, Hal 173-180.

Langrall, C. W., \& Mooney, E. S. 2005. Characteristics of elementary school students' probabilistic reasoning. In Exploring probability in school (pp. 95-119). Springer US.

Mari, J. S. 2012. Gender related differences in acquisition of formal reasoning schemata: pedagogic implication of teaching chemistry using process-based approaches. International Journal for Cross- 
Disciplinary Subjects in Education (IJCDSE). Vol. 2, No. 2, Hal 993997.

Moleong, L. 2009. Metodologi penelitian kualitatif. Bandung: PT. Remaja Rosdakarya.

Mooney, E. S., Langrall, C. W., \& Hertel, J. T. 2014. A Practitional Perspective on Probabilistic Thinking Models and Frameworks. In Probabilistic Thinking (pp. 495507). Springer Netherlands.

Mousoulides, N. G., \& English, L. D. 2009. Kindergarten students' understanding of probability concepts. In Proceedings of the 33rd Conference of the International Group for the Psychology of Mathematics Education (Vol. 4, pp. 137-144). International Group for the Psychology of Mathematics Education (PME).

Nikiforidou, Z., \& Pange, J. 2010. The notions of chance and probabilities in preschoolers. Early childhood education journal. Vol. 38, No. 4, Hal 305-311.

Paul, M., \& Hlanganipai, N. 2014. The nature of misconceptions and cognitive obstacles faced by secondary school mathematics students in understanding probability: A case study of selected Polokwane secondary schools. Mediterranean Journal of Social Sciences. Vol. 5, No. 8, Hal 446-455.

Pfannkuch, M., \& Brown, C. M. 1996. Building on and challenging students' intuitions about probability: Can we improve undergraduate learning. Journal of Statistics Education. Vol. 4, No. 1, Hal 39-53.

Polaki, M. V. 2002. Using instruction to identify key features of Basotho elementary students' growth in probabilistic

thinking. Mathematical Thinking and Learning. Vol. 4, No. 4, Hal 285-313.

Santrock, J. W. 2003. Adolescense perkembangan remaja edisi keenam. Alih (S. B. Adelar, Trans.). Jakarta: Erlangga.

Sari, D. I. 2015. Strategi dan representasi siswa sekolah dasar berjenis kelamin perempuan dalam menyelesaikan tugas probabilitas. Jurnal Apotema. Vol. 1, No. 2, Hal 47-58.

Sari, D. I. 2015. Profil berpikir probabilistik siswa sekolah dasar (SD) berkemampuan matematika tinggi dalam menyelesaikan tugas probabilitas. In Prosiding seminar nasional matematika dan pendidikan matematika UNY 2015, Yogyakarta, Hal 1123-1130.

Sari, D. I. 2015. Profil berpikir probabilistik siswa sekolah dasar (SD) berkemampuan matematika rendah dalam menyelesaikan tugas probabilitas. Media Penelitian Pendidikan: Jurnal Penelitian dalam Bidang Pendidikan dan Pengajaran. Vol. 9, No. 2, Hal 2936.

Sari, D. I., Budayasa, I. K., \& Juniati, D. 2017. Probabilistic thinking of elementary school students in solving probability tasks based on math ability. In AIP Conference Proceedings, 1867(1), 020028, AIP Publishing.

Sari, D. I., Budayasa, I. K., \& Juniati, D. 2017. The analysis of probability task completion; Taxonomy of probabilistic thinking-based across gender in elementary school students. In AIP Conference Proceedings, 1868(1), 050004, AIP Publishing.

Sari, D. I., Budayasa, I. K., \& Juniati, D. 2018. Perkembangan berpikir 
ISSN 2089-8703 (Print) Vol. 7, No. 1 (2018)

ISSN 2442-5419 (Online)

probabilistik siswa sekolah dasar.

Jurnal Riset Pendidikan dan Inovasi

Pembelajaran

Matematika

(JRPIPM). Vol. 1, No. 1.

Savard, A. 2014. Developing Probabilistic Thinking: What About People's Conceptions?. In Probabilistic Thinking (Hal. 283298). Springer Netherlands.

Sharma, S. 2012. Cultural influences in probabilistic thinking. Journal of Mathematics Research. Vol. 4, No. 5.

Way, J. 2003. The development of young children's notions of probability. In Proceedings of CERME (Vol. 3).

Way, J. 2008. Chance connections. Paper presented at the mathematical association of victoria. http://www.mav.vic.edu.au/files/co nferences/2008/Way/WayJ2008.do c diakses 7 Desember 2017

Yenilmez, A., Sungur, S., \& Tekkaya, C. 2005. Investigating Students' Logical Thinking Abilities: The Effects of Gender and Grade Level. Hacettepe University Journal of Education. Vol. 28, Hal 219-225. 